\title{
Interleukin-1 Influences Ischemic Brain Damage in the Mouse Independently of the Interleukin-1 Type I Receptor
}

\author{
Omar Touzani, ${ }^{*}$ Herve Boutin, ${ }^{*}$ Rosalind LeFeuvre, Lisa Parker, Andy Miller, Giamal Luheshi, and \\ Nancy Rothwell
}

School of Biological Sciences, University of Manchester, M13 9PT, United Kingdom

The cytokine interleukin-1 $\beta$ (IL-1 $\beta)$ contributes to ischemic, excitotoxic, and traumatic brain injury. IL-1 $\beta$ actions depend on interaction with a single receptor (IL-1RI), which associates with an accessory protein (IL-1RAcP), and is blocked by IL-1 receptor antagonist (IL-1ra). Here we show that in normal mice [wild-type (WT)], intracerebroventricular injection of IL-1ra markedly reduces $(-50 \% ; p<0.01)$ ischemic brain damage caused by reversible occlusion of the middle cerebral artery, whereas injection of IL-1 $\beta$ exacerbates damage $(+45 \%$; $p<$ 0.05).

Mice lacking IL-1RI [IL-1RI knock-out (KO)] exhibited ischemic brain damage that is almost identical to that of the WT (infarct volume $43.7 \pm 6.1$ and $46.2 \pm 6.2 \mathrm{~mm}^{3}$, respectively), but failed to respond to injection of IL-1ra. However, injection of $\mathrm{IL}-1 \beta$ (intracerebroventricularly) exacerbated ischemic brain damage in IL-1RI KO (+61\%; $p<0.001)$ and in WT mice $(+45 \%)$. This effect of IL- $1 \beta$ was abolished by heat denaturation in all animals, and was reversed by IL-1ra in WT, but not IL-1RI KO mice. In contrast, IL-1RI KO mice were completely resistant to effects of $\mathrm{IL}-1 \beta$ on food intake or body weight. IL1RAcP mRNA was increased by stroke in WT, but reduced in IL-1RI KO mice compared with sham-operated mice. Type II $\mathrm{IL}-1$ receptor mRNA was significantly increased $4 \mathrm{hr}$ after ischemia in WT and IL-1RI KO (+20\%) animals.

These data show that IL-1 $\beta$ can exacerbate ischemic brain damage independently of IL-1RI and suggest the existence of additional signaling receptor or receptors for IL-1 in the brain.

Key words: cerebrovascular accident; brain infarction; receptors; interleukin-1; mice; knock-out; cytokines
The cytokine interleukin-1 (IL-1) has diverse actions in the brain, where it has been identified as a mediator of several forms of neurodegeneration (Rothwell et al., 1997; Touzani et al., 1999). Expression of both forms of IL-1 (IL- $1 \alpha$ and IL-1 $\beta$ ) is increased rapidly in response to experimental or clinical insults, such as head injury, cerebral ischemia, infusion of excitotoxins, seizures, or CNS infections, and in diseases such as Parkinson's disease, amyotrophic lateral sclerosis, multiple sclerosis, epilepsy, and Alzheimer disease (Mogi et al., 1994; Touzani et al., 1999; Zhu et al., 1999; Mrak and Griffin, 2000). Thus, understanding the mechanisms of IL-1 action in the brain is of considerable biological and clinical importance.

In rodents, intracerebroventricular administration of recombinant IL- $1 \beta$ fails to cause cell damage directly, but markedly exacerbates ischemic, excitotoxic, or traumatic brain injury (Yamasaki et al., 1995; Loddick and Rothwell, 1996; Allan et al., 2000). In contrast, administration of the naturally occurring IL-1

\footnotetext{
Received June 21, 2001; revised Oct. 2, 2001; accepted Oct. 11, 2001.

This work was supported by the Medical Research Council (United Kingdom) and the European Union Training and Mobility in Research program. We are grateful to Immunex Corporation (Seattle, WA) for providing IL-1 receptor knockout mice and to Dr. Steve Poole (National Institute for Biological Standards and Controls, Potters Bar, UK) for providing IL-1. We also thank Anthea Hughes for her contribution to this work.

*O.T. and H.B. contributed equally to this work.

Correspondence should be addressed to Prof. Nancy Rothwell, School of Biological Sciences, 1.124 Stopford Building, University of Manchester, M13 9PT, UK. E-mail: Nancy.Rothwell@man.ac.uk.

O. Touzani's present address: Université de Caen-Unité Mixte de Recherche Centre National de la Recherche Scientifique 6551, Centre Cyceron, Boulevard H. Becquerel BP 5229, 14074 Caen, France.

G. Luheshi's present address: The Douglas Hospital Research Center, 6875 Boulevard Lassale, Verdun, Quebec H4R 1R3, Canada.

Copyright (C) 2001 Society for Neuroscience $\quad 0270-6474 / 01 / 220038-06 \$ 15.00 / 0$
}

receptor antagonist (IL-1ra) to rodents attenuates, by $>50 \%$, neuronal damage caused by such insults (Relton and Rothwell, 1992; Garcia et al., 1995; Toulmond and Rothwell, 1995; Loddick and Rothwell, 1996; Lawrence et al., 1998).

IL-1 is believed to exert all of its actions by binding to a single receptor (IL-1RI, $80 \mathrm{kDa}$ ) (Dinarello, 1996). Signal transduction is elicited by interaction of this receptor with an accessory protein (IL-1R AcP) (Greenfeder et al., 1995; Wesche et al., 1997). IL-1ra also binds to the IL-1RI, but fails to cause association with IL-1RAcP or initiate signal transduction, and acts as a highly selective, competitive, receptor antagonist, which blocks all the known actions of IL-1 (Arend et al., 1998). Mice lacking the IL-1RI fail to show the normal responses to IL-1, such as suppression of appetite and fever (Labow et al., 1997). A second IL-1 receptor (IL-1RII; $68 \mathrm{kDa}$ ) binds IL-1, but fails to initiate signal transduction, and can limit the biological activity of IL-1 (Colotta et al., 1994).

In spite of these established mechanisms of IL-1 action, some significant questions remain about IL-1 receptors in the CNS. IL-1RI is expressed in brain regions such as the hippocampus and choroid plexus (Takao et al., 1992; Loddick et al., 1998; French et al., 1999), but is barely detectable at major sites of IL-1 action (i.e., the hypothalamus and striatum) (French et al., 1999; Allan et al., 2000). By contrast, IL-1RAcP, which as far as is known, serves only to bind to IL-1RI, is expressed much more abundantly than IL-1RI, throughout the brain (Liu et al., 1996; Loddick et al., 1998). There has thus been much speculation about the presence of additional IL-1 receptors in the brain (Glaccum et al., 1997; Rothwell, 1999; Born et al., 2000; Rothwell and Luheshi, 2000). The objective of this study was to determine the role of IL-1RI in brain damage, by studying the effects of injections of 
IL-1 $\beta$ and IL-1ra on neuronal death induced by cerebral ischemia in wild-type (WT) and IL-1RI knock-out (IL-1RI KO) mice.

\section{MATERIALS AND METHODS}

Mice. Experiments were performed on male WT (C57xSV129, F2 generation) and IL-1RI KO mice kindly provided by Immunex Corporation (Seattle, WA). WT mice were compared with those in which the IL-1 receptor (IL-1RI) gene had been deleted by homologous recombination (IL-1RI KO) (Glaccum et al., 1997). Successful deletion of IL-1RI has been previously confirmed by Southern blot analysis (Glaccum et al., 1997) and was verified in the mice used in the present study by PCR analysis of genomic DNA, using the following primers:

5'-GAGTTACCCGAGGTCCAG-3', 5'-GAAGAAGCTCACGTTGTC-3', 5'-GCGAATGGGCTGACCCGCT-3'.

The animals were housed in a controlled environment of $12 \mathrm{hr}$ light/ dark cycle (8:00 A.M. to 8:00 P.M.) at $22^{\circ}$ C. All experiments were performed in accordance with United Kingdom legislation under the 1986 Animals (Scientific Procedures) Act.

The animals were studied at $8-10$ weeks of age and weighed between 24 and $32 \mathrm{gm}$ at the time of use. Anesthesia was induced by inhalation of $4 \%$ halothane and maintained with halothane (1.0-1.5\%) in $\mathrm{N}_{2} \mathrm{O}$ and $\mathrm{O}_{2}$ (70 and 30\%). Body temperature was maintained during the whole surgical procedure at $36.5-37.5^{\circ} \mathrm{C}$ with a heating lamp.

In parallel, the cerebrovasculature of the animals was examined using intracardiac injection of carbon black ink. WT and IL-1RI KO mice were anesthetized with pentobarbital (pentobarbitone sodium; $250 \mathrm{mg} / \mathrm{kg}$, i.p.). An incision was performed along the thorax to expose the heart, and the left cardiac ventricle was cannulated and perfused with $4 \%$ paraformaldehyde (PFA) for $5 \mathrm{~min}(2 \mathrm{ml} / \mathrm{min}$ ), followed by ink (Quink Parker) diluted in PFA 4\% (1:5 v/v). Brains were carefully removed, left in 4\% PFA overnight, and the Circle of Willis and major arteries were carefully examined under surgical microscope (Stemi SV11; Leica-Zeiss).

Induction of cerebral ischemia. Focal cerebral ischemia was induced by occlusion of the right middle cerebral artery (MCA) using the intraluminal filament technique (Clark et al., 1997; Hata et al., 1998). After midline neck incision, the common carotid artery (CCA) was isolated and ligated proximally with a 6.0 silk suture. The external carotid artery was also isolated and cauterized. A 6.0 silk suture was placed around the internal carotid artery to avoid bleeding through the arteriotomy when introducing the filament into the CCA. A nylon monofilament (8.0; Ethicon) coated with "thermo-melting" glue (Jet Melt; Radiospares) was introduced through an incision in the CCA, and advanced gently up to the origin of the MCA. The diameter of the tip was $180 \mu \mathrm{m}$. Animals were maintained under anesthesia throughout the $30 \mathrm{~min}$ period of ischemia. This duration of ischemia was chosen because it induces a reproducible injury, whereas longer durations were associated with significant mortality. To allow reperfusion, the occluding filament was withdrawn gently. The animals were then allowed to recover from anesthesia. In sham-operated mice, the same surgical procedure was performed, except that the filament was not advanced to occlude the MCA.

Measurement of cerebral blood flow. In each animal, laser doppler flowmetry (Moor Instruments) was used to monitor cerebral blood flow (CBF) continuously, before and during MCA occlusion (MCAo), and during reperfusion. After a small incision of the skin overlying the temporalis muscle, a $0.7 \mathrm{~mm}$, flexible, laser Doppler probe (model P10; Moor Instruments) was positioned on the superior portion of the temporal bone $(6 \mathrm{~mm}$ lateral and $2 \mathrm{~mm}$ posterior from the bregma) and secured with glue. This position corresponded to the center of the ischemic territory. Animals were included only when CBF was reduced by $>70 \%$ during ischemia, and successful reperfusion was subsequently achieved.

Measurement of infarct volume. Twenty-four hours after MCAo (when damage is complete in this protocol), mice were killed by anesthetic overdose with halothane and decapitated. Brains were removed and frozen in cooled $\left(-30^{\circ} \mathrm{C}\right)$ isopentane. Coronal brain sections were cut serially $(20 \mu \mathrm{m}$ at $200 \mu \mathrm{m}$ intervals) with a cryostat and stained with cresyl fast violet to identify viable tissue. The infarcted area was quantified (blind to the primary investigator), by automated image analysis (Scion Imaging, Cambridge, UK). To correct for the effect of edema, the infarcted area was determined indirectly by subtracting the area of the healthy tissue in the ipsilateral hemisphere from the area of the contralateral hemisphere on each section, as described previously (Lin et al.,
1993). Infarction volume was calculated by integration of infarct areas measured in 10 equidistant brain slices that encompassed the whole lesion.

Administration of substances. Guide cannulas were implanted stereotaxically into the right lateral cerebral ventricle of the brain under halothane anesthesia (1.5\% in $\mathrm{N}_{2} \mathrm{O}-\mathrm{O}_{2}$ at 70:30), $7 \mathrm{~d}$ before MCAo, to permit administration of substances intracerebroventricularly. All drugs were dissolved in sterile, $0.9 \%$ saline and administered randomly into the cerebral ventricles $30 \mathrm{~min}$ before occlusion and $10 \mathrm{~min}$ after reperfusion (i.e., $40 \mathrm{~min}$ after induction of MCAo). For each administration, a volume of $1 \mu \mathrm{l}$ was infused over $5 \mathrm{~min}$. Recombinant mouse IL- $1 \beta$ was a generous gift from Dr. Steve Poole (NIBSC, UK). Human recombinant IL-1ra was purchased from Preprotech (Rocky Hill, NJ).

Measurement of food intake and body weight. Animals were housed individually for these studies. Intake of normal food (Beekay) was measured over a period of $24 \mathrm{hr}$ after intracerebroventricular $(1 \mu \mathrm{l})$ injection of vehicle ( $0.9 \%$ saline) or IL-1 $\beta(2.5 \mathrm{ng})$ as described above, at 8:00 P.M. Body weight was recorded just before injection and again $24 \mathrm{hr}$ later.

Standard-calibrated competitive RT-PCR. Competitive RT-PCR was used to quantify IL-1RII and IL-1RAcP expression and conducted as described previously (Allan et al., 2000), with some modifications. PCR amplification was performed with specific primers for IL-1RAcP: sense 5'-TCCTCTGGACTTACCCTGATCT-3', antisense 5'-AACCCTTATACCAAGTGACCG-3' (354 bp product) and IL-1RII: sense 5'AGATGAGCCAAGGATGTGGG-3', antisense 5'-ATCAATAGGCGTGTGGGGTC-3' (339 bp product).

The PCR program (cycling profile) was $3 \mathrm{~min}$ at $95^{\circ} \mathrm{C}$, then denaturation at $95^{\circ} \mathrm{C}$ for $30 \mathrm{sec}$, annealing at $64^{\circ} \mathrm{C}$ (IL-1R AcP) or $62^{\circ} \mathrm{C}$ (IL-1RII) for $30 \mathrm{sec}$, and extension at $72^{\circ} \mathrm{C}$ for $1 \mathrm{~min}$ repeated for $36 \mathrm{cycles}$, and a 10 min final extension period at $72^{\circ} \mathrm{C}$. The absence of PCR products in control samples without reverse transcription of RNA was confirmed, and restriction enzyme digests of the RT-PCR products were performed to provide additional confirmation of the primer and product specificity. Competitive cRNA standards were synthesized using the conventional forward primer with a standard reverse primer:

IL-1RAcP:5'-ACCCTTATACCAAGTGACCGGTGAATACCCTGTTCAATAT-3';

IL-1R2:

5'-ATCAATAGGCGTGTGGGGTCTATACCACTGTATCTTTCCA-3'

to give products that were shorter (IL-1RAcP: 303 bp; IL-1RII 289 bp) than the conventional product, but were amplified by the original primers (Celi et al., 1993). Results, determined by comparison with the competitive standard, were expressed as percentage of change compared with tissue from sham-operated animals. Quantification of PCR product (picograms per microgram of total mRNA) has been done using Northern Eclipse image analysis software, and potential changes were expressed as percentage of sham-operated groups.

Data analysis. The data are presented as mean \pm SEM. To determine differences in infarct volumes between groups, a multiparametric ANOVA was performed with two factors: strain (WT or IL-1RI KO) and treatment (saline, IL-1 $\beta$, or IL-1ra) followed by PLSD Fisher post hoc test (Statview 5.0). Food intake and body weight changes were analyzed through the use of unpaired $t$ tests. For mRNA expression, a MannWhitney $U$ test was used to compare sham-operated versus MCAo mice, and WT versus IL-1RI KO mice. For CBF data, a repeated-measure ANOVA was undertaken with three factors: time (as repeated factor), strain, and treatment, and no further analysis was required because the ANOVA did not reach statistical significance. Statistical significance was considered as a probability of $<5 \%$ (two-tailed).

\section{RESULTS}

\section{Food intake and body weight}

Vehicle-treated animals exhibited normal food intake and showed the expected increase in body weight over the period of measurement (Fig. 1). In accordance with published data, intracerebroventricular administration of IL-1 $\beta$ (2.5 ng, i.c.v.), significantly inhibited voluntary food intake $(-60 \% ; p<0.001)$ and reduced body weight $(-1.8 \mathrm{gm} ; p<0.001)$ in WT mice over $24 \mathrm{hr}$, but failed to alter these parameters in IL-1RI KO mice (Fig. 1). 


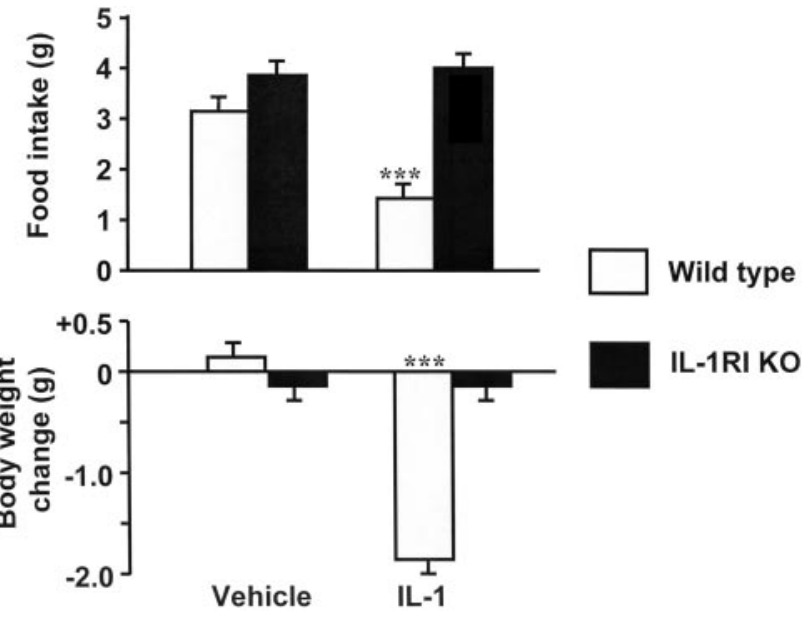

Figure 1. Effects of injection vehicle (saline) or recombinant IL-1, injected intracerebroventricularly on food intake $(a)$ and body weight $(b)$ in WT (open bars) and IL-1RI knock-out mice (closed bars). Food intake and body weight were measured over $24 \mathrm{hr}$ after injections. Mean values $\pm \mathrm{SEM} ; n=6$ per group; $* * * p<0.001$ versus respective vehicletreated group (unpaired $t$ test).

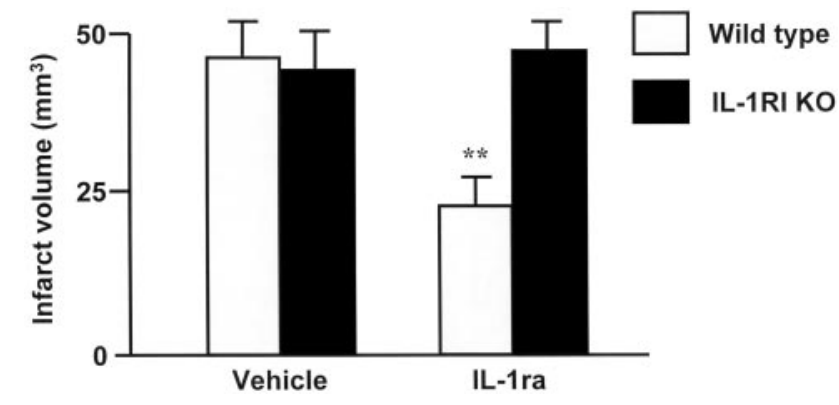

Figure 2. Extent of injury (infarct volume, $\mathrm{mm}^{3}$ ) measured $24 \mathrm{hr}$ after MCAo in wild-type (open bars) and IL-1RI knock-out mice (closed bars) injected intracerebroventricularly with vehicle (saline) or IL-1ra $(2.5 \mu \mathrm{g}$ $30 \mathrm{~min}$ before and again $40 \mathrm{~min}$ after MCAo). Data are mean values \pm SEM; $n=8$ per group; $* *<0.01$ versus respective saline-treated group (ANOVA and PLSD Fisher post hoc test).

\section{Damage caused by MCAo and effects of IL-1ra}

Study of the gross cerebrovasculature did not reveal any difference between WT and IL-1RI KO mice (data not shown).

Brain damage studied $24 \mathrm{hr}$ after temporary MCAo was almost identical in WT $\left(46.2 \pm 6.2 \mathrm{~mm}^{3}\right)$ and IL-1RI KO mice $(43.7 \pm$ $6.1 \mathrm{~mm}^{3}$ ) (Fig. 2). Intracerebroventricular injection of saline did not modify significantly the volume of infarction compared with no treatment in any mice (data not shown). Injection of IL-1ra (2.5 $\mu$ g, i.c.v.), administered $30 \mathrm{~min}$ before and $40 \mathrm{~min}$ after MCAo (10 min after reperfusion), significantly reduced infarct volume in WT mice $(-50 \% ; p<0.01)$ compared with saline administration, but had no effect on damage in IL-1RI KO mice (Fig. 2). Edema did not differ significantly between any of the groups studied $(8.3 \pm 3.5,10.0 \pm 2.4,7.2 \pm 4.2$, and $14.2 \pm 2.6$ $\mathrm{mm}^{3}$ in WT/saline, WT/IL-1ra, IL-1RI KO/saline, and IL-1RI $\mathrm{KO} / \mathrm{IL}-1 \mathrm{ra}$, respectively). Rectal temperature at the time of occlusion was not different between groups (WT/saline, $37.0 \pm$ 0.1 and $\mathrm{WT} / \mathrm{IL}-1 \mathrm{ra}, 36.9 \pm 0.1$; IL-1RI KO/saline, $37.1 \pm 0.0$ and IL-1RI KO/IL-1ra, $37.1 \pm 0.1^{\circ} \mathrm{C}$ ). Analysis of CBF did not show any difference between WT and IL-1RI KO or between groups receiving any treatment, and $\mathrm{CBF}$ was reduced by

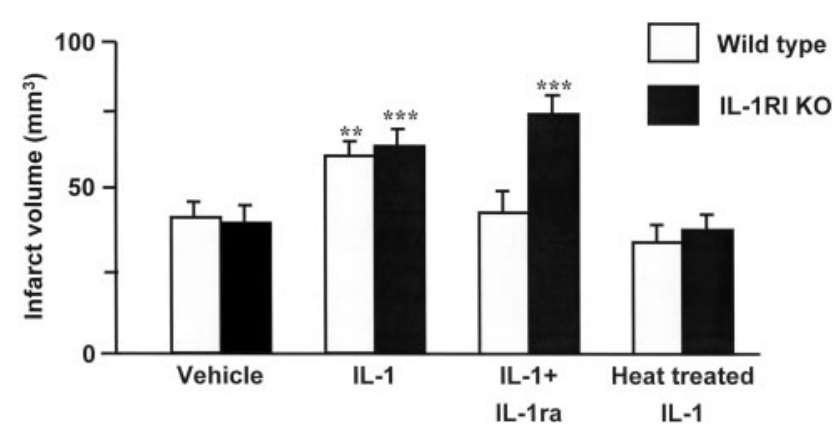

Figure 3. Effect of vehicle IL-1, IL-1 plus IL-1ra, or heat-treated IL-1 on infarct volume measured $24 \mathrm{hr}$ after MCAo in WT (open bars) and IL-1RI KO (closed bars). Mean values \pm SEM; $n=8$ for vehicle; $n=9$ for IL-1-treated animals; $n=6$ for IL-1 + IL-1ra and heat-treated IL-1treated animals. ${ }^{* *} p<0.01 ; * * p<0.005$ versus respective saline-treated group (ANOVA and PLSD Fisher post hoc test).

$>75 \%$ in all groups during MCAo compared with preocclusion values.

\section{Effects of IL-1 $\beta$ on MCAo-induced damage}

IL-1 $\beta$ (2.5 ng, i.c.v.) administered, $30 \mathrm{~min}$ before and $40 \mathrm{~min}$ after MCAo, resulted in marked increase in infarct size in WT $(45 \%$; $p<0.01)$ and in IL-1RI KO mice $(61 \% ; p<0.01)$ (Fig. 3). These IL-1-induced increases in infarct volume were completely prevented by heat denaturation of IL- $1 \beta\left(95^{\circ} \mathrm{C}\right.$ for $\left.45 \mathrm{~min}\right)$ (Fig. 3). Coadministration of IL-1ra prevented the increase in injury induced by IL- $1 \beta$ in WT mice, but failed to influence the effect of IL- $1 \beta$ in IL-1RI KO mice ( $+86 \%$ increase vs saline in IL-1RI $\mathrm{KO}$ mice; $p<0.005$ ) (Fig. 3). However, in WT mice, IL-1ra did not completely block the effect of IL-1, because WT mice receiving IL-1 $\beta$ and IL-1ra (Fig. 3) had a larger infarct than those receiving IL-1ra alone (Fig. 2) (WT/IL-1 $\beta+$ IL-1ra, $48.9 \pm 7.7$ $\mathrm{mm}^{3}$ versus $\left.\mathrm{WT} / \mathrm{IL}-1 \mathrm{ra}, 23.0 \pm 4.5 \mathrm{~mm}^{3} ; p<0.01\right)$. A lower dose of IL-1 $\beta(1.25 \mathrm{ng})$ given before and after induction of ischemia, induced a more modest increase in brain damage in WT $(20 \%)$ and IL-1RI KO mice (31\%) (data not shown). IL-1 $\beta$ injection did not induce significant changes in CBF (data not shown) or body temperature measured during surgery in WT and IL-1RI KO mice $\left(37.1 \pm 0.1^{\circ} \mathrm{C}\right.$ in both strains receiving IL-1, $36.9 \pm 0.2$ and $37.0 \pm 0.1^{\circ} \mathrm{C}$ in $\mathrm{WT} / \mathrm{IL}-1+\mathrm{IL}-1 \mathrm{ra}$ and IL-1RI KO/IL-1+IL-1ra, respectively) $\mathrm{KO}$ mice. In parallel, brain edema was not significantly different between WT and IL-1RI (WT/saline, $8.3 \pm 3.5$ $\mathrm{mm}^{3} ; \mathrm{WT} / \mathrm{IL}-1,10.6 \pm 2.8 \mathrm{~mm}^{3} ; \mathrm{WT} / \mathrm{IL}-1+\mathrm{IL}-1 \mathrm{ra}, 14.1 \pm 5.3$ $\mathrm{mm}^{3}$; IL-1RI KO/saline, $7.2 \pm 4.2 \mathrm{~mm}^{3}$; IL-1RI KO/IL-1, $13.8 \pm$ $2.6 \mathrm{~mm}^{3}$; IL-1RI/IL-1 + IL-1ra, $21.1 \pm 6.9 \mathrm{~mm}^{3}$ ).

\section{Expression of IL-1RAcP and IL-1RII mRNA}

In sham-operated groups, the levels of IL-1RAcP and IL-1RII were slightly higher in IL-1RI KO than in WT mice at $4 \mathrm{hr}$ $(19.4 \pm 0.3$ vs $17.8 \pm 0.6 \mathrm{pg} / \mu \mathrm{g}$ mRNA and $62.5 \pm 0.8$ vs $58.5 \pm$ $1.2 \mathrm{pg} / \mu \mathrm{g}$ mRNA, respectively; $p<0.05$ ), whereas no difference was observed at $24 \mathrm{hr}$. After MCAo, expression of IL-1RAcP mRNA (Fig. 4a) in the ischemic hemisphere was increased significantly $(+15 \% ; p<0.01)$ at $4 \mathrm{hr}$ in wild-type mice, but was slightly reduced $(-8 \%)$ in the cortex of IL-1RI KO mice (Fig. $4 a$ ) compared with the sham-operated group, and no change was observed $24 \mathrm{hr}$ after MCAo. At $4 \mathrm{hr}$ after MCAO, the level of IL-1RAcP was significantly lower in IL-1RI KO mice compared with the WT mice $(17.8 \pm 0.3$ vs $20.4 \pm 0.2 \mathrm{pg} / \mu \mathrm{g} ; p<0.05)$. mRNA for IL-1RII was increased 4 and $24 \mathrm{hr}$ after MCAo in WT 

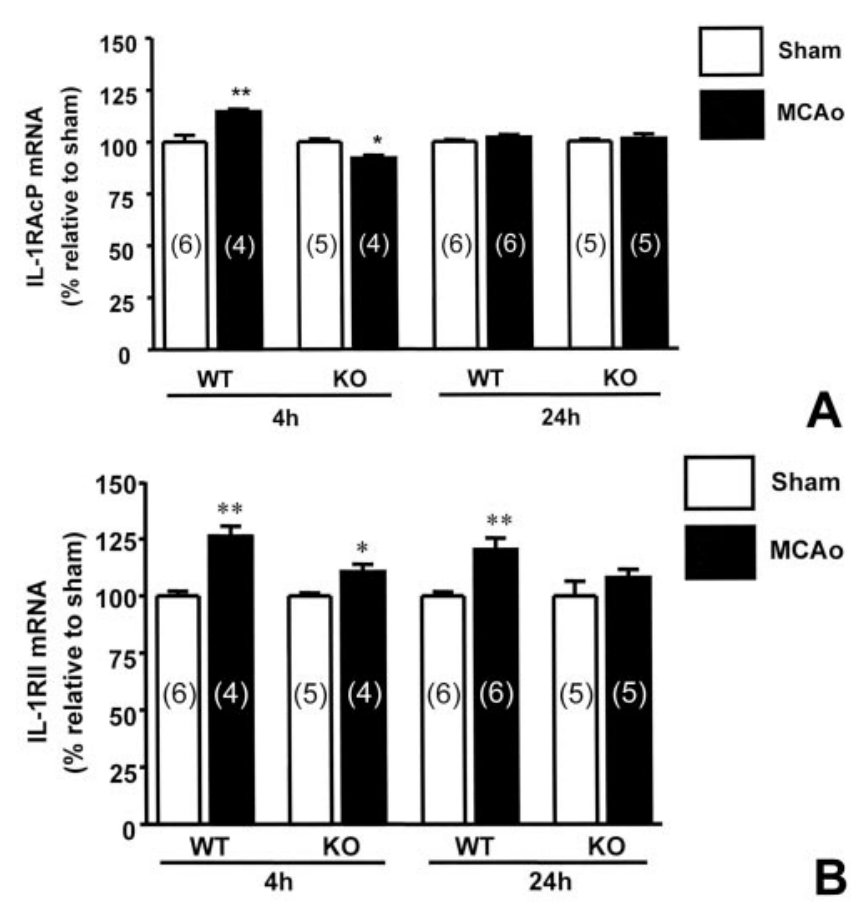

Figure 4. Expression determined by PCR analysis of IL-1RII $(A)$ and IL-1R AcP $(B)$ mRNA in cortex recorded 4 or $24 \mathrm{hr}$ after sham surgery or MCAo in WT (open bars) and IL-1RI KO mice (closed bars). Mean values $\pm \mathrm{SEM} ; n$ numbers are indicated in parentheses. ${ }^{*} p<0.05 ;{ }^{* *} p<$ 0.01 versus respective sham-operated groups (Mann-Whitney $U$ test).

mice $(+26$ and $+20 \%$, respectively; $p<0.01)$, and only at $4 \mathrm{hr}$ $(+11 \% ; p<0.05)$ in IL-1RI KO mice (Fig. $4 b)$.

\section{DISCUSSION}

The contribution of IL-1 to ischemic and other forms of acute brain damage is now well established in rodents. Several independent groups have reported early increases in expression of IL- $1 \beta$ in response to cerebral ischemia in rodents (Davies et al., 1999; Touzani et al., 1999; Legos et al., 2000). Injection of IL-1 $\beta$ does not cause neuronal damage, but exacerbates the lesion caused by cerebral ischemia, whereas administration of IL-1ra markedly reduces ischemic damage, and protection is sustained for at least 7 d (Relton and Rothwell, 1992; Martin et al., 1994; Garcia et al., 1995; Loddick and Rothwell, 1996; Relton et al., 1996; Legos et al., 2000). The results presented here in wild-type mice are in agreement with these previous published data on rodents and show for the first time in mice that injection of IL-1ra reduces infarct volume by $50 \%$, without influencing the severity of the primary insult (as determined from cerebral blood flow), whereas injection of IL- $1 \beta$ significantly enhanced damage $(+45 \%)$. The effect of IL-1 $\beta$ on ischemic brain damage was reversed by coadministration of IL-1ra in WT or by heat treatment of the cytokine in both WT and IL-1RI KO mice, indicating the specificity of its effects.

All actions of IL-1 are believed to depend on interaction with the IL-1RI, which must associate with IL-1R AcP to elicit intracellular signaling (Dinarello, 1996; Roux-Lombard, 1998), and activation of IL-1RI by IL-1 is blocked by IL-1ra (Arend et al., 1998). Thus, mice in which IL-1RI has been deleted by homologous recombination fail to show responses to IL-1 $\beta$ (e.g., on food intake, body temperature), and cells from these mice also fail to respond to IL-1 $\beta$ (Glaccum et al., 1997; Labow et al., 1997;
Josephs et al., 2000). In the present study, WT mice showed predicted reductions of food intake and body weight in response to intracerebroventricular injection of IL- $1 \beta$, but these responses were abolished in mice lacking IL-1RI. We also observed no effect of IL-1 $\beta$ (over a range of concentrations) on release of IL-6, or prostaglandin $\mathrm{E}_{2}$ or activation of c-Jun N-terminal protein kinase and extracellular signal-regulated kinase in mixed glial cultures from IL-1RI KO mice, whereas IL- $1 \beta$ induced significant responses in cells from WT cultures (data not shown).

There has been considerable speculation about the presence and function of additional IL- 1 receptors in the brain. IL-1RI is expressed at very low levels in the brain (Loddick et al., 1998; French et al., 1999), even at primary sites of IL-1 (and IL-1ra) action in neurodegeneration (i.e., the striatum and the hypothalamus) (Stroemer and Rothwell, 1997, 1998; Lawrence et al., 1998; Allan et al., 2000). In contrast, IL-1RAcP appears to be expressed more widely throughout the CNS (Liu et al., 1996). The data presented here show that IL- $1 \beta$ can exacerbate ischemic brain damage independently of IL-1RI in the mouse.

The volume of infarction (Fig. 2) and extent of edema (see above) caused by MCAo were very similar in WT and IL-1RI KO mice. This similarity may reflect compensatory changes in other putative mediators of neuronal death such as glutamate, nitric oxide, tumor necrosis factor- $\alpha$ or free radicals (Lee et al., 1999; Dirnagl et al., 1999). However we have observed that in mice lacking genes for both IL- $1 \alpha$ and $\beta$ exposed to an identical protocol of MCAo, infarct volume is reduced by $>70 \%$ compared with wild-type mice (Boutin et al., 2001). Thus, gene deletion of both IL-1 ligands dramatically reduces brain damage and is not associated with compensatory changes.

Injection of IL-1ra failed to influence infarct volume in IL-1RI $\mathrm{KO}$ mice, which is consistent with the interaction of IL-1ra with IL-1RI, and may support the proposal that damage in these mice is attributable to compensatory changes in other mediators of ischemic injury. However, injection of IL- $1 \beta$ induced a significant increase $(+61 \%)$ in infarct volume in mice lacking IL-1R1, which was similar to the increase of damage observed in WT mice. This increase in infarct volume was not related to changes in brain edema, or to an increase in body temperature measured during the period of surgery, which were similar in both strains receiving saline or IL-1, although core temperature may have increased after the period of surgery. The effect of IL-1 $\beta$ on infarct volume in IL-1RI KO mice was not modified by IL-1ra, but was abolished by heat treatment of IL- $1 \beta$.

The mechanisms underlying exacerbation of ischemic brain damage by IL- $1 \beta$, even in WT animals are not known. Actions of IL- $1 \beta$ on body temperature, endothelial, and blood-brain barrier injury, release of nitric oxide, free radicals, and eicosanoids and induction of molecules such as $\beta$-amyloid-protein precursor may contribute to the injury (Rothwell and Luheshi, 2000). Whether similar mechanisms operate in mice lacking IL-1RI is unknown. Kluger et al. (1996) and our data on IL- $1 \alpha$ and $\beta$ actions in the brain on fever (Anforth et al., 1998) suggest that IL-1 may induce fever through a new receptor.

The effects of IL- $1 \beta$ on ischemic brain damage reported here are very unlikely to be caused by nonspecific actions of IL- $1 \beta$ because: (1) actions of the same preparation of IL- $1 \beta$ on food intake, body weight (Fig. 1), or on signaling pathways involved in IL- $1 \beta$ action in mixed glial cultures (data no shown) were completely absent in mice or cells lacking IL-1RI, (2) heat treatment prevented the effects of IL- $1 \beta$ on ischemic brain damage, (3) the effects of this same preparation of IL- $1 \beta$ on fever are totally 
blocked by IL-1ra (data not shown), and (4) we tested another preparation of IL-1 $\beta$ from a totally different source, and this also exacerbated ischemic damage in IL-1RI KO mice (data not shown).

These observations lead to the conclusions that IL- $1 \beta$ can influence ischemic brain damage independently of IL-1RI and therefore presumably via another known or unknown receptor, which might be expressed only in the brain. It is possible that this reflects activation of a low-affinity receptor, or one that is induced only in the absence of IL-1RI, because IL- $1 \beta$ increased brain infarct in both WT and IL-1RI KO mice, whereas IL-1ra markedly reduced ischemic brain damage in WT mice and was ineffective in IL-1RI KO mice. Thus, under normal circumstances, IL-1 (and IL-1ra) may act predominantly through IL-1RI. However, IL-1ra consistently inhibits ischemic brain damage by $40-$ $60 \%$ (Touzani et al., 1999; Boutin et al., 2001), whereas deletion of both IL- $1 \alpha$ and IL- $1 \beta$ genes reduces such damage by $>70 \%$ (Boutin et al., 2001), suggesting that IL-1ra does not fully block all effects of IL- $1 \alpha$ and $\beta$. Furthermore, whereas IL-1ra seemingly prevented the effects of exogenous IL- $1 \beta$ on ischemic damage in WT animals, infarct volume was only returned to the level of injury observed in saline injected WT mice. Because a supramaximal dose of IL-1ra was used, damage in WT mice treated with IL-1 $\beta$ and IL-1ra (Fig. 3) should have been comparable with WT mice injected with saline and IL-1ra (Fig. 2). The fact that the volume of injury was considerably greater in the former group may suggest that an additional (i.e., not IL-1RI) receptor or receptors contribute to neurodegeneration in normal mice.

It seems unlikely that IL-1 can act through IL-1RII because the receptor has no intracellular domain, and its basal expression is only slightly modified in IL-1RI KO mice ( $+6 \%$ in $4 \mathrm{hr}$ shamoperated group, and NS in $24 \mathrm{hr}$ sham-operated group). Expression of IL-1RII was increased in WT and IL-1RI KO mice $4 \mathrm{hr}$ after ischemia, suggesting that it is regulated independently of IL-1RI, although association of IL-1RII with an unknown accessory protein may occur and could induce signal transduction. However, a potential association of IL-1RII with IL-1RAcP seems also unlikely because we showed in the present study a significant increase in IL-1RAcP mRNA level in WT mice compared with a decrease in IL-1RI KO mice after $4 \mathrm{hr}$ of MCAo, suggesting that the regulation of IL-1RAcP may be dependant of IL-1RI. In the absence of mice lacking IL-1RII or neutralizing antibodies to this receptor, the role of this receptor cannot yet be elucidated. Further investigation needs to be done to precisely clarify the potential role of IL-1RAcP in ischemic processes.

The nature, location, and signaling mechanisms of any additional IL-1 receptors in the brain are yet unknown, but could provide additional targets for modification of IL-1 actions.

\section{REFERENCES}

Allan SM, Parker LC, Collins B, Davies R, Luheshi GN, Rothwell NJ (2000) Cortical cell death induced by IL- 1 is mediated via actions in the hypothalamus of the rat. Proc Natl Acad Sci USA 97:5580-5585.

Anforth HR, Bluthe RM, Bristow A, Hopkins S, Lenczowski MJ, Luheshi G, Lundkvist J, Michaud B, Mistry Y, van Dam AM, Zhen C, Dantzer R, Poole S, Rothwell NJ, Tilders FJ, Wollman EE (1998) Biological activity and brain actions of recombinant rat interleukin1alpha and interleukin-1beta. Eur Cytokine Netw 9:279-288.

Arend WP, Malyak M, Guthridge CJ, Gabay C (1998) Interleukin-1 receptor antagonist: role in biology. Annu Rev Immunol 16:27-55.

Born TL, Smith DE, Garka KE, Renshaw BR, Bertles JS, Sims JE (2000) Identification and characterization of two members of a novel class of the interleukin-1 receptor (IL-1R) family. Delineation of a new class of IL-1R-related proteins based on signaling. J Biol Chem 275:29946-29954.

Boutin H, LeFeuvre RA, Horai R, Asano M, Iwakura Y, Rothwell NJ
(2001) Role of IL-1alpha and IL-1beta in ischemic brain damage. J Neurosci 21:5528-5534.

Celi FS, Zenilman ME, Shuldiner AR (1993) A rapid and versatile method to synthesize internal standards for competitive PCR. Nucleic Acids Res 21:1047.

Clark WM, Lessov NS, Dixon MP, Eckenstein F (1997) Monofilament intraluminal middle cerebral artery occlusion in the mouse. Neurol Res 19:641-648.

Colotta F, Dower SK, Sims JE, Mantovani A (1994) The type II “decoy” receptor: a novel regulatory pathway for interleukin 1 . Immunol Today 15:562-566.

Davies CA, Loddick SA, Toulmond S, Stroemer RP, Hunt J, Rothwell NJ (1999) The progression and topographic distribution of interleukin1beta expression after permanent middle cerebral artery occlusion in the rat. J Cereb Blood Flow Metab 19:87-98.

Dinarello CA (1996) Biologic basis for interleukin-1 in disease. Blood 87:2095-2147.

Dirnagl U, Iadecola C, Moskowitz MA (1999) Pathobiology of ischaemic stroke: an integrated view. Trends Neurosci 22:391-397.

French RA, VanHoy RW, Chizzonite R, Zachary JF, Dantzer R, Parnet P, Bluthé R-M, Kelley KW (1999) Expression and localization of p80 and p68 interleukin-1 receptor proteins in the brain of adult mice. J Neuroimmunol 93:194-202.

Garcia JH, Liu KF, Relton JK (1995) Interleukin-1 receptor antagonist decreases the number of necrotic neurons in rats with middle cerebral artery occlusion. Am J Pathol 147:1477-1486.

Glaccum MB, Stocking KL, Charrier K, Smith JL, Willis CR, Maliszewski C, Livingston DJ, Peschon JJ, Morrissey PJ (1997) Phenotypic and functional characterization of mice that lack the type I receptor for IL-1. J Immunol 159:3364-3371.

Greenfeder SA, Nunes P, Kwee L, Labow M, Chizzonite RA, Ju G (1995) Molecular cloning and characterization of a second subunit of the interleukin 1 receptor complex. J Biol Chem 270:13757-13765.

Hata R, Mies G, Wiessner C, Fritze K, Hesselbarth D, Brinker G, Hossmann KA (1998) A reproducible model of middle cerebral artery occlusion in mice: hemodynamic, biochemical, and magnetic resonance imaging. J Cereb Blood Flow Metab 18:367-375.

Josephs MD, Solorzano CC, Taylor M, Rosenberg JJ, Topping D, Abouhamze A, Mackay SL, Hirsch E, Hirsh D, Labow M, Moldawer LL (2000) Modulation of the acute phase response by altered expression of the IL-1 type 1 receptor or IL-1ra. Am J Physiol Regul Integr Comp Physiol 278:R824-R830.

Kluger MJ, Leon L, Kozak W, Soszynski D, Conn CA (1996) Cytokines actions on fever. In: Cytokines in the nervous system (Rothwell NJ, ed), pp 73-92. Austin, TX: Landes.

Labow M, Shuster D, Zetterstrom M, Nunes P, Terry R, Cullinan EB, Bartfai T, Solorzano C, Moldawer LL, Chizzonite R, McIntyre KW (1997) Absence of IL-1 signaling and reduced inflammatory response in IL-1 type I receptor-deficient mice. J Immunol 159:2452-2461.

Lawrence CB, Allan SM, Rothwell NJ (1998) Interleukin-1 $\beta$ and the interleukin-1 receptor antagonist act in the striatum to modify excitotoxic brain damage in the rat. Eur J Neurosci 10:1188-1195.

Lee JM, Zipfel GJ, Choi DW (1999) The changing landscape of ischaemic brain injury mechanisms. Nature 399:A7-A14.

Legos JJ, Whitmore RG, Erhardt JA, Parsons AA, Tuma RF, Barone FC (2000) Quantitative changes in interleukin proteins following focal stroke in the rat. Neurosci Lett 282:189-192.

Lin TN, He YY, Wu G, Khan M, Hsu CY (1993) Effect of brain edema on infarct volume in a focal cerebral ischemia model in rats. Stroke 24:117-121.

Liu C, Chalmers D, Maki R, De Souza EB (1996) Rat homolog of mouse interleukin-1 receptor accessory protein: cloning, localization and modulation studies. J Neuroimmunol 66:41-48.

Loddick SA, Rothwell NJ (1996) Neuroprotective effects of human recombinant interleukin-1 receptor antagonist in focal cerebral ischaemia in the rat. J Cereb Blood Flow Metab 16:932-940.

Loddick SA, Liu C, Takao T, Hashimoto K, De Souza EB (1998) Interleukin-1 receptors: cloning studies and role in central nervous system disorders. Brain Res Brain Res Rev 26:306-319.

Martin D, Chinookoswong N, Miller G (1994) The interleukin-1 receptor antagonist (rhIL-1ra) protects against cerebral infarction in a rat model of hypoxia-ischemia. Exp Neurol 130:362-367.

Mogi M, Harada M, Kondo T, Riederer P, Inagaki H, Minami M, Nagatsu $\mathrm{T}$ (1994) Interleukin-1 beta, interleukin-6, epidermal growth factor and transforming growth factor-alpha are elevated in the brain from Parkinsonian patients. Neurosci Lett 180:147-150.

Mrak RE, Griffin WS (2000) Interleukin-1, the immunogenetics of Alzheimer disease. J Neuropathol Exp Neurol 59:471-476.

Relton JK, Rothwell NJ (1992) Interleukin-1 receptor antagonist inhibits ischaemic and excitotoxic neuronal damage in the rat. Brain Res Bull 29:243-246.

Relton JK, Martin D, Thompson RC, Russell DA (1996) Peripheral administration of interleukin-1 receptor antagonist inhibits brain damage after focal cerebral ischemia in the rat. Exp Neurol 138:206-213. 
Rothwell NJ (1999) Annual review prize lecture cytokines-killers in the brain? J Physiol (Lond) 514:3-17.

Rothwell NJ, Luheshi GN (2000) Interleukin 1 in the brain: biology, pathology, therapeutic target. Trends Neurosci 23:618-625.

Rothwell N, Allan S, Toulmond S (1997) The role of interleukin 1 in acute neurodegeneration and stroke: pathophysiological and therapeutic implications. J Clin Invest 100:2648-2652.

Roux-Lombard P (1998) The interleukin-1 family. Eur Cytokine Netw 9:565-576.

Stroemer RP, Rothwell NJ (1997) Cortical protection by localized striatal injection of IL-1ra following cerebral ischemia in the rat. J Cereb Blood Flow Metab 17:597-604.

Stroemer RP, Rothwell NJ (1998) Exacerbation of ischemic brain damage by localized striatal injection of interleukin-1 beta in the rat. J Cereb Blood Flow Metab 18:833-839.

Takao T, Culp SG, Newton RC, De Souza EB (1992) Type I interleukin-1 receptors in the mouse brain-endocrine-immune axis labelled with [ ${ }^{125}$ I] recombinant human interleukin-1 receptor antagonist. J Neuroimmunol 41:51-60.
Toulmond S, Rothwell NJ (1995) Interleukin-1 receptor antagonist inhibits neuronal damage caused by fluid percussion injury in the rat. Brain Res 671:261-266.

Touzani O, Boutin H, Chuquet J, Rothwell N (1999) Potential mechanisms of interleukin-1 involvement in cerebral ischaemia. J Neuroimmunol 100:203-215.

Wesche H, Korherr C, Kracht M, Falk W, Resch K, Martin MU (1997) The interleukin-1 receptor accessory protein (IL-1RAcP) is essentia for IL-1-induced activation of interleukin-1 receptor-associated kinase (IRAK) and stress-activated protein kinases (SAP kinases). J Biol Chem 272:7727-7731.

Yamasaki Y, Matsuura N, Shozuhara H, Onodera H, Itoyama Y, Kogure K (1995) Interleukin-1 as a pathogenetic mediator of ischemic brain damage in rats. Stroke 26:676-680.

Zhu SG, Sheng JG, Jones RA, Brewer MM, Zhou XQ, Mrak RE, Griffin WS (1999) Increased interleukin-1beta converting enzyme expression and activity in Alzheimer disease. J Neuropathol Exp Neurol 58:582 587. 